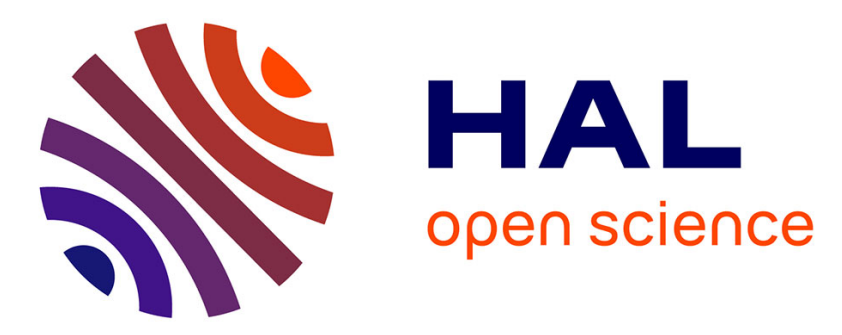

\title{
Geophysical estimation of the damage induced by an observatory digging in a limestone heterogeneous vadose zone - Beauce aquifer (France)
}

Céline Mallet, Clara Jodry, Gautier Laurent, Mohamed Azaroual

\section{- To cite this version:}

Céline Mallet, Clara Jodry, Gautier Laurent, Mohamed Azaroual. Geophysical estimation of the damage induced by an observatory digging in a limestone heterogeneous vadose zone - Beauce aquifer (France). EGU General Assembly 2020, May 2020, Online, France. 10.5194/egusphere-egu2020-2411. hal-03554443

\author{
HAL Id: hal-03554443 \\ https://hal.science/hal-03554443
}

Submitted on 3 Feb 2022

HAL is a multi-disciplinary open access archive for the deposit and dissemination of scientific research documents, whether they are published or not. The documents may come from teaching and research institutions in France or abroad, or from public or private research centers.
L'archive ouverte pluridisciplinaire HAL, est destinée au dépôt et à la diffusion de documents scientifiques de niveau recherche, publiés ou non, émanant des établissements d'enseignement et de recherche français ou étrangers, des laboratoires publics ou privés.

\section{(c)(1)}

Distributed under a Creative Commons Attribution| 4.0 International License 
EGU2020-2411

https://doi.org/10.5194/egusphere-egu2020-2411

EGU General Assembly 2020

(c) Author(s) 2022. This work is distributed under

the Creative Commons Attribution 4.0 License.

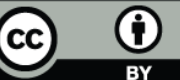

\section{Geophysical estimation of the damage induced by an observatory digging in a limestone heterogeneous vadose zone - Beauce aquifer (France)}

Céline Mallet ${ }^{1}$, Clara Jodry ${ }^{1}$, Gautier Laurent ${ }^{1}$, and Mohamed Azaroual ${ }^{1,2}$

'Univ. Orléans, CNRS, BRGM, ISTO, UMR 7327, F-45071, Orléans, France (celine.mallet@univ-orleans.fr)

${ }^{2}$ BRGM - French Geological Survey

The O-ZNS observatory offers a unique geophysical support for characterization, at different scales (from nano- to metric scales) of the heterogeneous Beauce Limestones aquifer. Currently under development at an agricultural site in Villamblain (Centre Val de Loire, France), this observatory is based on an exceptional well ( $20 \mathrm{~m}$-depth and $4 \mathrm{~m}$-diameter) associated with many external boreholes on an area of around $2400 \mathrm{~m}^{2}$. It will combine different geophysical techniques and innovative multi-geosciences sensors to image, monitor and understand fluid and heat transfers in the heterogeneous structure of the vadoze zone.

An initial geophysical characterization has been conducted with surface measurements (3D electrical resistivity imaging and 2D Magnetic Resonance Sounding) that gave interesting information on the lithology of O-ZNS site: a silty-clayed soil of a few meter thick, then a highly heterogeneous and karstified limestone and finally, the massive fractured limestone. Cross-hole radar measurements add to these information a description of the initial zone, the soil properties and the water content. Also, data from three boreholes and the collection of core samples as well as logging measurements completed and improved this initial characterization.

All these data have been used to develop a finite element numerical model representing both the study site and the well under Plaxis 2D. Through the realism of geotechnical engineering including deformation, stability and water flow, the idea, is to anticipate the effect of the digging and provide information about the induced damaged zone that will derive. We also look into describing the evolution of this damaged zone depending on the seasoning variation (i.e. from 3 to $5 \mathrm{~m}$ ) of the groundwater level. All these characterizations will allow us to better focus our field geophysical investigations on monitoring the damaged zone.

The model consists of a description of the different soil layers from the boreholes that includes elastic, microstructural and transport properties, followed by a description of the interface between the soil and the well. The hydraulic conditions will take into account the time-variability of fluxes and the aquifer level. Furthermore, this model is coupled with the construction phasing from a civil engineering point of view. The results will give the evolution of stress and strain induced by the engineering development of O-ZNS well in the host rock as well as an estimate of 
the material displacement and its elasticity limits. The preliminary modelling generated a result stipulating a damaged zone of 1-2 $\mathrm{m}$ around the well at the surface. The magnitude of the damaged zone is reduced with depth. It seems that, at the bottom, the host rock is undamaged.

Undergoing development are focused on refining the model by providing more effective and updated estimations of the soil and structure properties in order to validate or improve the first results together with an estimation of the time evolution of the damaged zone with the water saturation state. Afterward, we will be able to compare and validate these results to pictures and measurements performed during the digging that will start in the spring 2020. 